\title{
The Survey of Information Systems in Public Administration in Poland
}

\author{
Ewa Ziemba and Iwona Obłąk \\ University of Economics, Katowice, Poland
}

ewa.ziemba@ue.katowice.pl iwona.oblak@ue.katowice.pl

\begin{abstract}
The objective of this paper is to identify information systems that are implemented in public administration in Poland and to investigate their capabilities, benefits, and challenges. First of all, the paper describes the typology of information systems in public administration and identifies the benefits and challenges of their implementation. Next, the background of public administration in Poland is discussed. Then, research findings show examples of information systems implementation in Polish public administration. Special attention is paid to capabilities, benefits, and challenges of the information systems implemented in the social security area. The paper concludes with discussing its findings, implications, and avenues for further research. Overall, it is of value for audiences that include researchers and managers of public administration. It can serve as guidelines and sources for references which can stimulate further research.
\end{abstract}

Keywords: information systems, IS, information technology, ICT, public administration, government process, e-government, Poland

\section{Introduction}

There is a growing consensus among public administration across the world about the need to revitalize public administration to facilitate customer centered, cost-efficient, and user-friendly delivery of services to citizens and businesses (Gnan, Hinna, Monteduro, \& Scarozza, 2013; Gupta, Dasgupta, \& Gupta, 2008; Urciuoli, Hintsa, \& Ahokas, 2013). As a result of this, governments are introducing innovations in management, processes, government services, organizational structure, practices, and capacities (Arundel \& Huber, 2013; Dolfsma \& Seo, 2013; Reddick, 2011; van der Voet, 2013). This way they mobilize, deploy, and utilize the human capital as well as information, technological and financial resources for service delivery to citizens and businesses (Dhillon, 2005; Reddick \& Turner 2012; Torres, Pina, \& Acerete, 2005; Tung \& Rieck, 2005; Weerakkody, El-Haddadeh, Sabol, Ghoneim, \& Dzupka, 2012). Thereby they are improving the quality of governmental functions. Consequently, efficient and effective public

Material published as part of this publication, either on-line or in print, is copyrighted by the Informing Science Institute. Permission to make digital or paper copy of part or all of these works for personal or classroom use is granted without fee provided that the copies are not made or distributed for profit or commercial advantage AND that copies 1) bear this notice in full and 2) give the full citation on the first page. It is permissible to abstract these works so long as credit is given. To copy in all other cases or to republish or to post on a server or to redistribute to lists requires specific permission and payment of a fee. Contact Publisher@InformingScience.org to request redistribution permission. administration is an essential precondition for economic and social development (Adam, Delis, \& Kammas, 2011).

So far research has prioritized the studies on the effects of informationcommunication technologies (ICT) and information systems (IS) as a shortcut to increase public sector efficiency and improve internal administration and management capabilities (Arduini, 
Denni, Lucchese, Nurra, \& Zanfei, 2013; Cordella \& Bonina, 2012; Lozoya-Arandia \& FrancoReboreda, 2012; Vu, 2013; Ziemba \& Papaj 2013). Governments have largely conceived IS use as a further step in the reorganization of the public sector along the basic principles of efficiency gains and costs savings (Bekkers \& Homburg, 2007; Dunleavy, Margetts, Bastow, \& Tinkler, 2006; Heeks, 2002; Homburg, 2004).

Public administration is taking advantage of enhancing its performance, especially in terms of information and communication at the local, regional, national, and also international levels. The improvement of information flow and communication between government units at the different levels can lead to the meeting of goals - streamlining processes and increasing efficiency, sustaining and strengthening democracy, and improving government accountability and transparency. The use of IS is an essential component of a government strategy to succeed in a rapidly changing world.

Currently, implementing and managing IS in business organizations is an unprecedented condition for economic efficiency, which is quite extensively described in the literature. However, in public administration, IS implementation is not sufficiently investigated and presented in the literature. There are some descriptions about IS itself, though there are only a few studies on IS implementations and their support of government processes. The use of information systems enhances processes management in public administration and supply of public services, which are an ongoing research subject. The study of IS implementation in public administration requires a broad knowledge base and practical experience.

This paper provides an overview of information systems in public administration. It includes fundamental concepts of information systems and hands-on experience with selected information systems. It concentrates on IS deployment in public administration in Poland. The purpose of this paper is to identify IS which are implemented in public administration in Poland and to investigate their capabilities, benefits and challenges. The paper is organized as follows. Section Literature Review describes the typology of IS in public administration and identifies the benefits and challenges of IS implementation in public administration. At the end of this section the background of public administration in Poland is discussed. Section Research Findings shows examples of IS implementation in public administration in Poland. The capabilities, benefits and challenges of the information systems implemented in the social security area are indicated. The paper concludes with discussing its findings, implications, and avenues for further research. Overall, it is of value for audiences that include researchers and public administration mangers. It can serve as guidelines and sources for references which can stimulate further research.

\section{Literature Review - Information Systems in Public Administration}

\section{Typology of Information Systems}

IS in the public sector is a tool to support delivering new and better government services to government stakeholders by increasing efficiency and transparency and by improving accountability in public administration procedures and management (Bekkers \& Zouridis, 1999; Dunleavy et al., 2006; Gupta et al., 2008; Heeks, 2002). Researchers have pointed out that IS has long been considered as an activator of modernization in public administration or as a trigger for organizational changes (van de Donk \& Stellen, 1998).

The classification of IS implemented in public administration presents as follows: (1) Workflow Management Systems (WfMS), (2) Enterprise Information Systems (EIS), (3) Enterprise Application Integration (EAI), (4) Business Process Management Systems (BPMS), (5) Business Intelli- 
gence (BI), and (6) Enterprise Portals. Usually those systems are integrated with each other by service oriented architecture (SOA).

Workflow Management Systems (WfMS) are one of the most important systems that support the government processes. They manage workflow and perform manual actions associated with these processes (Sheth, Aalst, \& Arpinar, 1999). A workflow management system (WfMS) is defined as a system that partially or fully automates the definition, creation, execution, and management of work procedures (workflows). The Workflow Management Coalition has defined a workflow as "the automation of a business process, in whole or part, during which documents, information or tasks are passed from one participant to another for action, according to a set of procedural rules" (Workflow Management Coalition, 1999). WfMS are used in the public administration for the realization of processes connected with providing services for government clients (citizens and businesses), as well as document flows within government units and between them. They are also a link connecting other information systems enabling the flow of data among them (Saleem, Chung, Fatima, \& Dai, 2013).

Enterprise Information Systems (EIS) mainly embrace such systems as Enterprise Resource Planning (ERP), Transaction Systems (TS), and Customer Relationship Management systems (CRM). These systems enhance certain processes in their fields of operation, e.g., human resources processes, accounting processes, or processes of providing services for government clients. The data gathered and integrated in EIS systems most often supply BI systems (Lezochea, Yahiaa, Aubrya, Panettoa, \& Zdravkovic, 2012; Shang \& Seddon, 2002).

Enterprise Application Integration (EAI) acts as an integrator of the IS and allows for easy management of the flow of government processes (Linthicum, 2003; Samtani \& Sadhwani, 2002). It integrates systems such as ERP, CRM and Enterprise Portals into one system. EAI is rather a technology system than software one. The construction of EAI solutions, thanks to object oriented architecture, allows for defining and cataloging processes, procedures, ICT components or operating principles of government processes (Liu, Zhang, Xiong, \& Lv, 2006). EAI can simultaneously use different technologies (e.g., web services and WfMS ), which due to their differences complement each other perfectly, thereby integrating the flow of information in public administration even further (Jablonski, 2005).

Business Process Management Systems (BPMS) have been designed for the management processes within an organization, i.e., planning, defining, organizing, and monitoring processes (Winn \& Oo, 2011). BPMS systems combine information technology with management processes. Thanks to this they support users in implementing action sequences that make up the specified process (Gartner, 2010). These systems improve the phases of process life cycle, such as (1) discovery and model, (2) validation and simulation, (3) deployment and execution, (4) monitoring and performance management, and (5) improve (Pourshahid, Amyot, Peyton, Ghanavati, Chen, \& Weiss, 2009).

Business Intelligence (BI) systems have emerged as a technological solution offering data integration and analytical capabilities that provide government managers at various organizational levels with valuable information for their decision making (Olszak \& Ziemba, 2007; Turban, Sharda, \& Delen, 2010). For this purpose, they use data warehouse technology and advanced tools for multidimensional analysis and data exploration. BI systems are used in the public administration for the statistical analysis of operational and financial data. Their operation is based on resources of data and information collected by the public administration in various databases.

Enterprise portals provide a point of access to data and information from the intranet and extranet systems, ERP systems, TS systems, CRM systems, workflow management systems, e-learning systems, data warehousing, Business Intelligence, and others (Ziemba, 2009). Enterprise portals are designed to integrate diverse sources of information and provide knowledge workers with a 
single gateway, login and user-friendly browser interface to their personal working platforms (Dias, 2001). Enterprise portals are based on web technology. They supply information within government units to its employees, but also provide information outside the system to citizens, businesses, and other government units (Chang \& Wang, 2011).

Service oriented architecture (SOA) is a concept to create information systems in which services that meet specific user's requirements are defined (Wang, 2009). The concept of SOA is a set of technical and organizational methods designed to link the business side of the organization with its IT resources in a better manner. "A service-oriented architecture is a framework for integrating business processes and supporting ICT infrastructure as secure, standardized components - services - that can be reused and combined to address changing business priorities" (Bieberstein, Bose, Fiamante, Jones, \& Shah, 2005). SOA solutions are used to allow software applications to communicate with each other. Public administration through SOA technology integrates the flow of data from the currently implemented IS systems to aggregate data systems, such as BI. SOA technology integrates data flow between IS and provides access to full information in one place (Zorrilla \& García-Saiz, 2013). This, in turn, facilitates the provision of services for citizens and businesses (e.g. obtaining information regarding citizens from various registers).

\section{Information Systems Benefits and Challenges in Public Administration}

The key premise of IS implementation in public administration is attaining benefits. In particular that refers to benefits which translate into the quality of government services delivered to citizens and businesses. This is due to the fact that public administration is evaluated in terms of competitiveness and attractiveness for the clients of its services (Bhuiyan, 2011; Hwang \& Akdede, 2011; Pillania, 2011). Although each public administration is unique in its financial and economic activities, benefits and challenges are common to all of them (Kim, 2007).

In general, it can be stated that the benefits from an IS implementation must link in some way into the objectives of the provided government services itself. These benefits are attained both by government clients using government services, as well as government units. Benefits to government clients include (1) access to information for general public, (2) online services, and (3) access to timely, relevant and accurate information (Cordella \& Bonina, 2012; Gupta et al., 2008). The benefits to government units are (1) process redesign and standardization, (2) improved project management practice, (3) rigorous quality assurance, and (4) increased support and involvement from all levels of personnel (Bhuiyan, 2011; Torres et al., 2005; Tung \& Rieck, 2005). An indirect benefit of IS implementation in public administration is a belief that it will enhance the openness, transparency, and accountability of public administrations and will increase the awareness of citizens and businesses about accessible government services (Pina, Torres, \& Acerete, 2007).

Implementation of IS in public administration in Poland concentrates currently on attaining the following benefits (State 2.0, 2012):

- logical and effective circulation of information in government units at the local levels and the central level;

- operations of government units according to the defined government processes;

- integration of government data;

- easy access to government data and information for government units; and

- access of citizens and businesses to government information and e-government services from various media (PC, laptop, smartphone, tablet). 
IS implementation in public administration means far more than technology implementations. Successful IS implementation requires sufficient attention to policy, processes, structure, laws, and regulations (Rose \& Grant, 2010). While implementing, accounting for those issues is a big challenge for public administration. It is necessary to use various management concepts, such as knowledge management $(\mathrm{KM})$, change management $(\mathrm{CM})$, project management $(\mathrm{PM})$, quality management (QM), and risk management (RM), in order to minimize the risk of failure during IS implementation (Antošová, Csikósová, \& Mihalčová, 2013; Jallow, Majeed, Vergidis, Tiwari, \& Roy, 2007; Jeston \& Nelis, 2008; Lee, Kim, Seo, Kim, \& Kim, 2011; Trkman, 2010; Ziemba \& Obłąk, 2012). Moreover, it is necessary to use knowledge and former experience of government units appropriately so as to successfully implement IS. The best way to implement IS is to organize its implementation as a project. Every project should comply with appropriate quality criteria and eliminate the risk of failure that links with QM and RM respectively. Additionally, IS implementation results in many organizational changes which should be implemented according to $\mathrm{CM}$ principles. Consequently, IS implementation is a complex exercise in technology innovation and organizational change management and it is not an easy task (Kumar, Maheshwari, \& Kumar, 2002; Markus \& Tanis, 2000). It requires the coordination of many activities of an organization and a close cooperation of employees, managers, ICT specialists, business analysts, and consultants (Sambamurthy \& Kirsch, 2000). IS implementation, in fact, has become one of the most common solutions implemented to standardize work procedures and smoothen information flow (Cordella \& Iannacci, 2010).

This approach is leading to the changes prescribed by a new public management (NPM) ideology (Barzelay, 2001; Cordella \& Bonina, 2012). The most evident transformation proposed by NPM is to promote a management culture for the public sector that, as in the case of the private sector, becomes results driven, where the managerial efficiency supersedes the need for effectiveness in the delivery of government services (Self, 2000). In fact, the technology is only the customer facing front-end of a complex set of organizational structures, policies, and processes that are designed to provide particular services (Rose \& Grant, 2010). NPM, as the main driver of the public sector reforms, has resulted in several ambitious goals such as to make the public administration more responsive, accountable, transparent, and results-driven, as well as decentralized, efficient, and beneficiary oriented (Cordella \& Bonia, 2012).

\section{Public Administration in Poland}

The organizational structure of public administration in Poland presents as follows. The public administration system is complex and consists of a two level structure: central and local (voivodship). The operational scope of government units at the central level covers the entire country. Government units' operations at the local levels refer to a voivodship, a municipality or a district. Public administration in Poland is composed of the governmental centre (Council of Ministers and its dependent structures), Ministries, central administration, state organizational units, general field government administration, and field administrative bodies (Gierszewski, 2012). The structure of Polish public administration with a division into central and local bodies is presented in Table 1.

The structure of public administration is vital for IS implementation. However, the economic and social background has also significant impact on public administration shape and conditions and implementing IS (Ongondo, Williams, Dietrich, \& Carroll, 2013; Weber \& Kauffman, 2011). The factors related to the implementation of ICTs are dependent on different public administration styles although they have potential capacity to condition the offer of online developments by governments (Torres, Pina, \& Acerete, 2006). The most common social and economic factors in Poland are presented in Table 2. 


\begin{tabular}{|l|c|l|}
\hline \multicolumn{2}{|c|}{ Table 1: Public administration in Poland } \\
\hline \multicolumn{1}{|c|}{ Government units } & Level & \multicolumn{1}{c|}{ Examples } \\
\hline Governmental Centre & central & Government \\
\hline Ministries & central & Ministry of Administration and Digitization \\
\hline Central Offices & central & Central Statistical Office \\
\hline State Organizational Units & central & $\begin{array}{l}\text { The Constitutional Court } \\
\text { Supreme Control Office }\end{array}$ \\
\hline General field government administration & local & $\begin{array}{l}\text { State Fire Service } \\
\text { Regional Police }\end{array}$ \\
\hline Field administrative bodies & local & $\begin{array}{l}\text { Chamber of duty } \\
\text { Customs Chamber }\end{array}$ \\
\hline
\end{tabular}

\begin{tabular}{|l|r|l|}
\hline \multicolumn{3}{|c|}{ Table 2: Social, demographic and economic factors in Poland } \\
\hline \multicolumn{1}{|c|}{ Factors } & \multicolumn{1}{|c|}{ Data/Measure } & \multicolumn{1}{c|}{ Source } \\
\hline Government: & Parliamentary Republic & \\
\hline National legislature: & National Assembly & \\
\hline Language: & Polish & \\
\hline Currency: & $\begin{array}{l}\text { Zloty (PLN) } \\
\text { USD }=3.13 \text { PLN }\end{array}$ & Mid-market rates: 2013-11-11 UTC \\
\hline Population: & $38.5 \mathrm{~m}(2013)$ & Central Statistical Office in Poland \\
\hline Geographical territory: & $312.679 \mathrm{~km}$ & \\
\hline GDP (PPP) per capita: & $\$ 21,118\left(49^{\text {th }}\right)(2013)$ & International Monetary Fund \\
\hline Gini: & $30.90(2013)$ & $\begin{array}{l}\text { Gini coefficient of equalized disposable income } \\
\text { (source: SILC). Eurostat Data Explorer }\end{array}$ \\
\hline $\begin{array}{l}\text { Adult literacy rate } \\
\text { (percent, ages 15 and } \\
\text { above): }\end{array}$ & $99.52(2010)$ & $\begin{array}{l}\text { United Nations Educational, Scientific, and Cul- } \\
\text { tural Organization (UNESCO) Institute for Statis- } \\
\text { tics }\end{array}$ \\
\hline $\begin{array}{l}\text { Internet users } \\
\text { (per 100 people): }\end{array}$ & $62.00 \%(2013)$ & Central Statistical Office in Poland \\
\hline $\begin{array}{l}\text { Human Development Index } \\
\text { (HDI): }\end{array}$ & $0.82\left(39^{\text {th }}\right)(2012)$ & International Human Development Indicators \\
\hline $\begin{array}{l}\text { Urbanization } \\
\text { (urban population, percent): }\end{array}$ & $60.80 \%(2013)$ & Central Statistical Office in Poland \\
\hline
\end{tabular}

Economic conditions and levels of education are directly related to public administration performance as well as technological level and IS development in the country (Kim, 2007). In most developed European economies, IS development has advanced significantly in terms of the complexity of public administration services (Arduini et al., 2013; Seri \& Zanfei, 2013). Each nation has a different level of information technology development, a different level of the application of ICT to the public administration, and a different level of electronic government. In order to properly outline the research background the maturity of technology must be described. It is not without significance, that highly developed countries are moving their focus from basic IS implemen- 
tation and e-government to reengineering their internal operation radically to reduce costs of government delivering services (Weerakkody, Janssen, \& Dwivedi, 2011).

There are several indexes that measure information systems development (Ziemba \& Żelazny, 2013). In 2012 Poland placed 37th, with a 6.31 score, on the ICT Development Index, classifying Poland as a medium developed country (Measuring the Information Society, 2013). On an egovernment readiness index, Poland measured 4.19, placing 49th in 2013 (Insight Report, 2013).

Public maturity of public administration can also be measured. Using an eGovernment Maturity Model (eGov-MM), public administration is evaluated against international best practices in the area of e-Government, including the formulation of organizational strategies and policies, management of ICT, operative management, and organizational capabilities of human resources and the organization overall (Valdés, Solar, Astudillo, Iribarren, Concha, \& Visconti, 2011). Poland scored at the fourth maturity level but the use of e-government services was rated unsatisfactory and needs some improvement (Ziemba \& Papaj, 2013).

Public administration in Poland is under reorganization from a functional management model to a business process orientation (BPO) model. The transition from one model into another allows public administration to be focused on customer satisfaction and manage business processes (Kasprzak, 2005). The aim of complex IS implementation is to define and support processes in public administration. The understanding of the essence of public administration processes directly translates into successful IS implementation (Barjis, 2008).

In Poland there are ambitious initiatives to improve public administration and government services for government clients. There is a program of digitalizing Polish public administration which consists of many IS implementation projects (State 2.0,2012).

\section{Research Methodology}

This study is a part of research on the holistic and systems approach to the e-government adoption in the context of sustainable information society (Ziemba, 2013).

The goal of our research was to identify IS that are implemented in public administration in Poland and to investigate their capabilities, benefits, and challenges. Such a spectrum of work involves adaptation of research methods to specific individual tasks and requires the use of different research tools, allowing for clarification and verification of results. In order to achieve the research goals, various scientific methods and techniques have been applied, such as a critical analysis of literature, a review of Polish government reports, an analysis of Polish IS projects in public administration, case studies, action research, as well as methods of creative thinking and logical deduction.

In order to present the impact of information systems on public administration in Poland this research took the following steps:

1. The first step - a review of the literature was conducted to identify information systems for public administration and their benefits and implementation challenges. The presentation of public administration in Poland is based on a literature review and different government reports.

2. The second step - basing on case studies of IS projects in public administration in Poland, the list of implemented and planned IS was established.

3. The third step - capabilities, benefits and challenges of Emp@tia information system were indicated on the basis of action research. The action research means a coordination and a participation in the projects on implementing information system in public administration. 
4. The fourth step - basing on literature findings, empirical observations and methods of creative thinking and logical deduction, a conclusion and implications were formulated.

\section{Research Findings - Information Systems in Polish Public Administration}

\section{Identification of Information Systems}

Analyzing the procurement of information systems and the reports of public administration in Poland (Michalek-Budzicz, Malujda, \& Michalski, 2011), the following conclusions arise. At the central level, the public administration mainly implements dedicated systems, such as WfMS, EIS, EAI, BPMS, and Enterprise Portals. These systems are often integrated with BI systems. They are mostly based on SOA and use Web 2.0 technology. At the local level, public administration largely implements WfMS, designed to support the service of citizens and businesses. There are also implemented Enterprise portals and EIS, mainly ERP. They are often used in public procurement systems and geographic information systems (Geographic Information Systems GIS). A large part of the implementations are computer trading systems dedicated to the handling of government processes related to e -government services rendered by the public administration, e.g., issues related to the service of citizens.

According to the report of the Ministry of Administration and Digitization in 2012 (State 2.0, 2012) at both levels of public administration, the central and local levels, were undergoing projects connected with designing, implementing and developing IT systems presented in Table 3. A detailed characteristic of those systems is presented in Table A1 in the Appendix.

\begin{tabular}{|c|c|}
\hline \multicolumn{2}{|r|}{$\begin{array}{l}\text { Table 3: IT projects in public administration in Poland - } \\
\text { already implemented and during implementation }\end{array}$} \\
\hline Name of the system & Objectives \\
\hline $\begin{array}{l}\text { New Land and Mort- } \\
\text { gage Register (NKW) }\end{array}$ & $\begin{array}{l}\text { The project objective is to improve conditions for running business operations in the real } \\
\text { estate market and the convenience of individuals by ensuring better access of natural and } \\
\text { legal persons to the IT Land and Mortgage Register. }\end{array}$ \\
\hline $\begin{array}{l}\text { Location and Informa- } \\
\text { tion Platform with } \\
\text { Central Database (Pol- } \\
\text { ish acronym PLI CBD) }\end{array}$ & $\begin{array}{l}\text { The Location and Information Platform with Central Database is a part of the nationwide IT } \\
\text { Emergency Communication System. The platform itself is used to maintain the database with } \\
\text { data on the users of public telephone networks and to provide the systems and services, } \\
\text { which are responsible for receiving emergency calls, with information on end locations of } \\
\text { (fixed and mobile) telephone networks, from which emergency calls were made }\end{array}$ \\
\hline $\begin{array}{l}\text { Country-wide data } \\
\text { communication net- } \\
\text { work to support emer- } \\
\text { gency phone number } \\
\text { "112" }\end{array}$ & $\begin{array}{l}\text { The objective of the project is to implement an integrated nationwide data communication } \\
\text { network to support emergency phone number 112, including terminals for the appropriate } \\
\text { rescue services and public order services (Police, Fire Brigade, Provincial Emergency Com- } \\
\text { munication Centers, Provincial Offices), as well as to provide mechanisms for the manage- } \\
\text { ment, maintenance and monitoring of the network status and service quality. }\end{array}$ \\
\hline $\begin{array}{l}\text { Integrated, multi- } \\
\text { service communication } \\
\text { platform for the Police } \\
\text { with e-Services for } \\
\text { individuals and busi- } \\
\text { nessmen } \\
\end{array}$ & $\begin{array}{l}\text { To build a system supporting police services through electronic channels. The system must } \\
\text { also make police work more efficient. The e-auctions module must allow sales through Inter- } \\
\text { net auctions, while e-orders must support handling of public orders. }\end{array}$ \\
\hline $\begin{array}{l}\text { Public Statistics Infor- } \\
\text { mation System (SISP) }\end{array}$ & $\begin{array}{l}\text { To strengthen the role of public statistics in the state's information infrastructure by imple- } \\
\text { menting e-Statistics, that is, by providing a system for public communication of statistics }\end{array}$ \\
\hline $\begin{array}{l}\text { Electronic Services } \\
\text { Platform (PUE) for } \\
\text { customers }\end{array}$ & $\begin{array}{l}\text { The main objective of the project at its strategic level is to increase access to ZUS services } \\
\text { offered in electronic form and distributed over various access channels down to individuals } \\
\text { and businessmen. }\end{array}$ \\
\hline
\end{tabular}


Development of the ZUS IT system supporting access to eServices

Emp@tia - a communication platform for

the social security area

Georeference Database of Topographic Objects and the national management system
Improved continuity, efficiency, and security of services provided to the public by the ZUS (e-Services included). This will ensure a better accessibility and security of electronic services provided to payers, a better performance of the technical and systemic infrastructure which is used by systems serving ZUS inspectors via the Internet.

Building a broad communication platform for the social security area that will enable delivering and providing electronic services to both, welfare beneficiaries, family allowance users,

the alimony fund, small and medium-sized enterprises which serve as technological suppliers to the data communications systems supporting the welfare security area.

TERYT2--The national The project will open on-line access to the state registry of plot boundaries and areas of the registry of plot bounda- state territory division units, and it will implement solutions related to the operation of adries and areas of state dress registers. During the project implementation, a new-quality register will be set up by territory division units. expanding and supplementing the existing descriptive data bases (e.g., TERYT) through adding to them the relevant geometric data and descriptive data integrated with the existing graphic data.

Infrastructure of the Finance Ministry eServices

Project implementation will ensure efficient rendering of e-Services to the public and business sectors, and will enhance the use of e-Services by providing appropriate information support for the infrastructure of e-Services rendered by the Finance Ministry. It will, moreover, provide a flexible data transmission environment to the remote network of the Finance Ministry, to stimulate the development of advanced public services offered over electronic channels (including information exchange between the systems of the Finance Ministry and their Central EU Systems.

The system of informa- This project comprises of building a System of Information about Broadband Infrastructure-tion about Broadband Infrastructure and the "Broadband Poland" portal a data communications system for gathering, processing, presenting, and releasing information about the telecommunication infrastructure, public telecommunication networks, and buildings used for collocation. The objective of the System of Information about the Broadband Infrastructure project is to build up knowledge about the data communications infrastructure with nationwide reach, that will give support to central and local government administration in its management and co-ordination of projects related to building a regional, broadband framework and access networks in areas requiring intervention. This infrastructure will support the work of central and local government by providing support for the electronic public services provided to the individuals and entrepreneurs. An additional aim of the project is to promote information society services among the residents of areas threatened with digital exclusion.

Central Registry and Information about Business Activities (CEIDG)

The main objective of the Project is to implement a system for building up and running a central registry of businesses, providing information about the entries in the central business records, in-creasing the security of business transactions by providing information about entrepreneurs entered in the registry of enterprises.

IT System for Protect- The fundamental objective of the project is to create an uniform IT system, ready for coming the Country against mon use, in order to protect the society against emergencies and to support a decisionEmergencies making process if life and health threatening events occur in a given area.

Geoportal 2

The main objective of the project is to enable citizens universal access to and use spatial information in Poland through the expansion of the national spatial information infrastructure in the scope of georeferencing registers and related services. Data collected as a part of GBDOT project is, among others, published. The project assumes the integration and harmonization of services and spatial information through the use of georeferencing/ base registers, as well as the co-ordination of activities in accordance with the State's information infrastructure model and assumptions of the INSPIRE Directive.

pl.ID - Polish ID card - Rebuild, upgrade and integrate the existing state registers,

- Ensure compatibility with the European electronic identity document (eID),

- Computerize the registers of Registry Offices,

- Implement electronic ID card with an option of authentication in the IT systems of public sector entities. 


\begin{tabular}{|c|c|}
\hline $\begin{array}{l}\text { Building and equipping } \\
\text { the Emergency Infor- } \\
\text { mation Centers }\end{array}$ & $\begin{array}{l}\text { Improve the security of citizens and foreigners present in the territory of Poland: integration } \\
\text { of the services on duty at the respective entities appointed by the law to provide rescue in } \\
\text { particular, the Fire Brigades, the Police Force, and the State Medical Aid, to significantly } \\
\text { improve the collaborative efficiency of those structures. Cut short the response time and } \\
\text { improve the success rate of alarms sent to rescue services and structures. Improve the work- } \\
\text { ing conditions of public order enforcement and rescue officers/staff through providing ser- } \\
\text { vices which guarantee quick access to information. Rational spending public money through } \\
\text { minimization of the cost of organization and current operation of the Emergency Information } \\
\text { System. }\end{array}$ \\
\hline $\begin{array}{l}\text { Electronic Platform to } \\
\text { Gather, Analyse, and } \\
\text { Release Digital Re- } \\
\text { source on Medical } \\
\text { Events (P1) } \\
\end{array}$ & $\begin{array}{l}\text { The main objective of the project is to allow public organs, including the central and local } \\
\text { government agencies, businessmen, and the public to gather, analyze, and release digital } \\
\text { resource on medical events, improve the processes of planning and providing health services, } \\
\text { and publishing information on health protection subjects. }\end{array}$ \\
\hline $\begin{array}{l}\text { Platform available on- } \\
\text { line to entrepreneurs } \\
\text { who need access to } \\
\text { services and digital } \\
\text { medical registry re- } \\
\text { source (P2) }\end{array}$ & $\begin{array}{l}\text { The aim of this project is to build an electronic platform of public services in the health } \\
\text { protection sector: "Platform available on-line to entrepreneurs who need access to services } \\
\text { and digital medical registry resource." The detailed objective of the project is to promote } \\
\text { electronic communication among companies and public entities of the health sector. }\end{array}$ \\
\hline $\begin{array}{l}\text { Building an electronic } \\
\text { services system for the } \\
\text { Ministry of Justice }\end{array}$ & $\begin{array}{l}\text { The main objective of the project is to improve the conditions of doing business by giving } \\
\text { individuals and companies an electronic information platform of the Ministry of Justice on } \\
\text { which services requiring communication with the administration of justice will be available. }\end{array}$ \\
\hline e-Deklaracje2 & $\begin{array}{l}\text { The main objective of the project is to improve the process of information exchange between } \\
\text { the tax authorities and its clients. }\end{array}$ \\
\hline e-Taxes & $\begin{array}{l}\text { The strategic objective of the project is to simplify the system of tax collection by improving } \\
\text { the internal business processes in the tax administration. }\end{array}$ \\
\hline e-Registration & $\begin{array}{l}\text { The main goal of the Project is facilitation of the registration and recording procedures of tax } \\
\text { payers and payers. }\end{array}$ \\
\hline Program e-Duty & $\begin{array}{l}\text { The main goal of the e-Duty Project is the creation of an ICT systems environment enabling } \\
\text { the implementation of digital systems for customs clearances, and at the same time securing } \\
\text { the best possible conditions for functioning of Companies in the Customs Union. Thanks to } \\
\text { the building and integration of the components of the e-Duty Program conditions will be } \\
\text { created for a successful, secure and effective exchange of data with businessmen, custom } \\
\text { administrations of other Member States and the European Commission and collaborating } \\
\text { institutions, what will be the implementation of a Community initiative "e-Customs" on } \\
\text { national ground. }\end{array}$ \\
\hline $\begin{array}{l}\text { ePUAP2 - Electronic } \\
\text { Platform of Public } \\
\text { Administration Ser- } \\
\text { vices }\end{array}$ & $\begin{array}{l}\text { The main goal of the ePUAP2 project is the creation of one, easy accessible and secure chan- } \\
\text { nel for making available public services to citizens and granting access to a Trusted Profile } \\
\text { for the authorization of the citizen in contact with the administration. }\end{array}$ \\
\hline
\end{tabular}

Source: based on (State 2.0, 2012).

Polish government has also plans for future IT projects. Those are presented in Table 4 and in Table A2 in the Appendix.

Future plans for IS in administration concentrate on the citizens' participation in the processes of decision-making and change implementation. Their main impact will focus on improving services for the public and delivering an open access to state resources in various areas.

The implemented IS are mainly of central reach covering the entire country. They are very often linked to the IS implemented at the local levels, because they use transactional data entered into these systems. The systems implemented at the central level provide information the local units of government, where they are subsequently processed within the government process. 
Table 4: IT projects in public administration in Poland - planned

\begin{tabular}{|l|l|}
\hline Name of the system & Objectives \\
\hline $\begin{array}{l}\text { Platform for e-Services } \\
\text { of Office of Electronic } \\
\text { Communications }\end{array}$ & $\begin{array}{l}\text { The project objective is to develop an IT system for the Office of Electronic Communica- } \\
\text { tions. }\end{array}$ \\
\hline $\begin{array}{l}\text { Integrated electronic } \\
\text { platform for collecting, } \\
\text { analyzing and making } \\
\text { state audit results avail- } \\
\text { able }\end{array}$ & $\begin{array}{l}\text { The objective of the project is to strengthen and modernize the state control exercised by } \\
\text { the Supreme Audit Office through streamlining the auditing process implemented by the } \\
\text { Supreme Audit Office in the areas of planning, implementation, monitoring and making } \\
\text { available audit results }\end{array}$ \\
\hline $\begin{array}{l}\text { Business Information } \\
\text { Centre (Polish acronym } \\
\text { CIG) of the Ministry of } \\
\text { Justice }\end{array}$ & $\begin{array}{l}\text { The main objective of this project is to extend the scope of access by natural and legal } \\
\text { persons to information and data collected and processed by the units of the Ministry of } \\
\text { Justice (this applies to information resources contained in the court registers of New Land } \\
\text { and Mortgage Register, National Court Register, Register of Pledges, Court and Business } \\
\text { Gazette) }\end{array}$ \\
\hline
\end{tabular}

Source: based on (State 2.0, 2012).

\section{Capabilities, Benefits and Challenges of Emp@tia Information Systems}

The implementation of IS systems in the Polish public administration is often of complex nature. This research concentrates on Emp@tia information systems because they are a very good example of the complexity of information systems and cover processes on different levels of the organization. As in the case of "Emp@tia - a communication platform for the social security area", implemented for the needs of the Ministry of Labour and Welfare Policy (MPiPS) (http://empatia.mpips.gov.pl/). The main goal of the project is to build a broad communication platform for the social security area that will enable delivering and providing electronic services. The services will be rendered to welfare beneficiaries, family allowance users, the alimony fund, and small and medium-sized enterprises.

The specific objectives of Emp@tia project are:

- consolidation, consistency, and ensuring information interoperability between the subsystems of the social security system;

- ensuring interoperability of the systems outside the social security system (e.g., CEPiK, PUE ZUS, PESEL, TERYT, e-Delaracje, EESSI UE, eGUS, CEIDG, KRS, GeoPortal);

- the provision of electronic services for government clients (including applicants for social benefits; and

- provision of electronic services related to the implementation of the statutory tasks by government employees (including employees of administrative units of social security area).

The project began in 2009, and its completion is scheduled for the end of 2013. As a result of the project there will be created:

- the central integration platform, which consists of EAI, WfMS, and is lined to BI system analyzing data from a locally installed systems EIS;

- enterprise portal linked to an information portal of MPiPS; and

- mobile terminal software supplying data to local EIS systems.

At the central level, the implemented systems include Integrated Application Management System (EAI), Business Intelligence (BI), enterprise portal, and workflow management system (WfMS). In contrast, at the local level there are improved transactional systems belonging to the class of EIS systems, which will provide the automatic flow of data to the EAI at the central level. 
The systems use SOA architecture, which correlates data flow. In addition, the implemented project is only part of a wider concept of the integration of IS in public administration at the central level. The information systems implemented in the project EMP@TIA are presented in Figure 1.

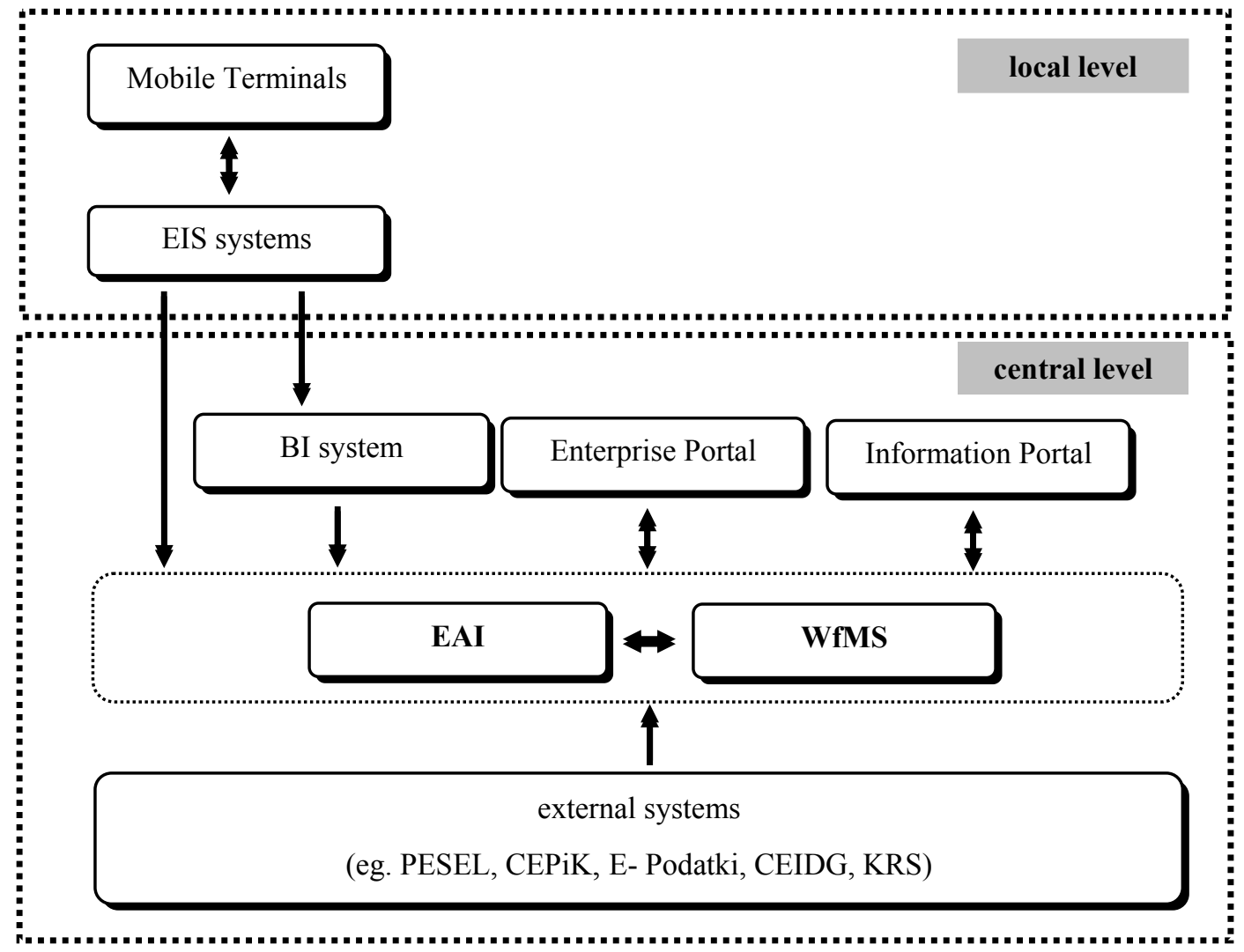

Figure 1. Information systems implemented within the frame of Emp@tia project

The project has been undertaken in response to the diagnosed problems associated with a lack of integration of information systems. The lack of integration excluded, inter alia, the ability to obtain quickly information necessary for the effective operation and monitoring of the work of the administration units and caused inefficient flow of information between the public administration units and institutions cooperating. The lack of cooperation between systems also contributed to the difficulty in monitoring the allocation and disbursement of funds for social security benefits and difficulties in monitoring the use of funds by the various administrative units.

The implemented information systems are to improve the flow of information, which has so far been paper based. This will have a significant impact on the duration of government processes, in which an official has a direct contact with government clients. To a large extent, these processes will be implemented through an internet portal. Government clients will be able to submit applications electronically to a specified e-mail address; they will also receive response to submitted applications. Government employees will have access to consolidated information through EAI. EAI using the resources of the EIS, BI, and external systems will allow users to aggregate information about government clients in one place. The necessary information will be obtained practically in a few moments, and not a few days, as it has been the case so far. 
Furthermore, the implementation of the BI system will allow for a statistical analysis of data obtained from locally deployed EAI. In turn, the acquired data will enable the creation of reports based on the multi-level, cross-sectional analysis of social benefits paid across the country.

\section{Discussion}

Currently, public administration is increasingly implementing information systems. This makes it possible to extend the efficiency and effectiveness of government processes and government services for citizens and businesses. This paper makes an effort to make some contribution to the development of studies on factors for successful information systems implementation in public administration. It identifies information systems implemented in public administration and explores their capabilities, benefits, and challenges.

In summary, for the information systems implementation to be successful and to bring tangible benefits to government units and their clients, it is necessary to meet some basic issues.

Firstly, implementation of information systems in public administration faces various challenges which need to be examined with the view of their future scope of operation. During the IS implementation at the local and central level of public administration, the main challenges are:

- complex approach to IS implementation embracing organizational changes which are to be carried out;

- planning for integration and the integration of implemented IS with the already existing systems or those that are scheduled for implementation;

- focus on IS functionality for its users (government clients and government employees), not technological aspects of implementation;

- preventing the risk of insufficient cooperation with IS users;

- adjusting implemented IS to the actual and future needs of its users, which are the subject to continuous changes e.g. due to the changes to legal regulations;

- division of a project, such as IS implementation, into stages, including scheduling for feasibility stage and pilot implementation of IS; and

- scheduling for the maintenance of implemented IS.

Additionally, while implementing IS for the whole country the following should be accounted for:

- coordination of IS implementation across the country;

- maintaining a logical sequence in IS implementation across the country;

- designing a coherent links and relationships between IS across the country.

On the basis of the carried out studies, it can be stated that IS implemented at the central level are linked with IS at the local levels. The central system very often passes the information to the systems operating locally by individual government units.

Secondly, studying information systems implemented in Polish public administration and the case study on the IS implementation for the support of the social security area allowed for the identification of types of information systems useful for public administration. These are (1) Workflow Management Systems - WfMS, (2) Enterprise Information Systems - EIS, (3) Enterprise Application Integration - EAI, (4) Business Process Management Systems - BPMS, (5) Business Intelligence systems (BI), and (6) Enterprise portals. It is necessary to integrate the implemented IS and standardize the transmitted information. This is possible thanks to SOA technology.

Thirdly, studying the impact of IS on the growth of efficiency of the public administration, some factors should be taken into account, namely those that accompany the implementation of IS and at the same time greatly impinge on the successful implementation of IS. Those factors include: 
- introducing improvements and modifications to the existing government processes;

- introducing legal changes;

- introducing procedural and organizational changes in public administration units.

Fourthly, IS implementation radically changes previously defined government processes. After the IS implementation, their provision will not be possible in the current manner. Therefore, their prior modification accounting of the use of IS is necessary. This requires not only changes in activities implemented within the processes, but also organizational changes, as, for example, the scope of responsibilities of individuals in charge of single processes and tasks completed within the framework of the assigned change.

\section{Conclusion}

Generally, this study helps provide some insights that can lead to improved implementation of information systems in public administration, in Poland and other developing countries. By identifying the information systems implemented in Poland, implications for both research and practice come to the fore. From a research perspective, e-government in developing countries provides very fertile soil. Specifically, researchers can conduct in depth quantitative and qualitative studies to identify barriers and determinants of information systems implementation. Moreover, the methodological issue of IS implementation in public administration will be possible to be explored.

Furthermore, there are implications by the use of the example of information systems for government practitioners while undertaking empirical activities aimed at implementing IS successfully and effectively. Government units and government authorities could find answers to important contemporary questions, in particular: What kind of IS could be implemented in public administrations? What are the capabilities of IS in public administration? What are the benefits of IS implementation in public administration? What factors influence the successful implementation of IS in public administration? What are the challenges during the IS implementation in public administration?

The replication of this study in emerging and developing countries will be useful to improve their knowledge related to the issues of IS implementation in public administration.

Furthermore, the issues of information systems implementation in public administration showed in this research that they should be explored in greater depth. There is a need to conduct research, especially into (1) improvement of government processes by using government process management and ERP systems, (2) improvement of government management by using BI systems, (3) exploration of "best practices" to be used to successfully implement ERP and BI systems in public administration, and (4) investigation of influence of ERP and BI systems on the development and standard of the provided government services delivered by government units. Those will be considered as future work.

\section{Acknowledgement}

This research has been supported by a grant entitled "Designing a system approach to sustainable development of the information society - on the example of Poland" from the National Science Centre in Poland, 2011/01/B/HS4/00974, 2011-2014. 


\section{References}

Adam, A., Delis, M. D., \& Kammas, P. (2011). Are democratic governments more efficient? European Journal of Political Economy, 27, 75-86.

Antošová, M., Csikósová, A., \& Mihalčová, B. (2013). Application knowledge management in the practice of business subjects in Slovakia. In Procedia - Social and Behavioral Sciences, 83, 975-979.

Arduini, D., Denni, M., Lucchese, M., Nurra, A., \& Zanfei, A. (2013). The role of technology, organization and contextual factors in the development of e-Government services: An empirical analysis on Italian Local Public Administrations. Structural Change and Economic Dynamics, 27, 177-189.

Arundel, A., \& Huber, D. (2013). From too little to too much innovation? Issues in measuring innovation in the public sector. Structural Change and Economic Dynamics, 27, 146-159.

Barjis, J. (2008). The importance of business process modeling in software systems design. Science of Computer Programming, 71, 73-87.

Barzelay., M. (2001). The new public management. Improving research and policy dialogue. Oxford: University of California Press.

Bekkers, V., \& Homburg, V. (2007). The myths of e-government: Looking beyond the assumptions of a new and better government. The Information Society, 23, 373-382.

Bekkers, V., \& Zouridis, S. (1999). Electronic service delivery in public administration: Some trends and issues. International Review of Administrative Sciences, 2, 183-195.

Bhuiyan, S. H. (2011). Modernizing Bangladesh public administration through e-governance: Benefits and challenges. Government Information Quarterly, 28, 54-65.

Bieberstein, N., Bose, S., Fiammante, M., Jones, K., \& Shah, R. (2005). Service-oriented architecture (SOA) compass: Business value, planning, and enterprise roadmap. IBM Press.

Chang, H. H., \& Wang, I. Ch. (2011). Enterprise information portals in support of business process, design teams and collaborative commerce performance. International Journal of Information Management, 31, 171-182.

Cordella, A., \& Bonina, C. M. (2012). A public value perspective for ICT enabled public sector reforms: A theoretical reflection. Government Information Quarterly, 29, 512-520.

Cordella, A., \& Iannacci, F. (2010). Information systems in the public sector: The e-Government enactment framework. Journal of Strategic Information Systems, 19, 52-66.

Dhillon, G. (2005). Gaining benefits from IS/IT implementation: Interpretations from case studies. International Journal of Information Management, 25, 502-515.

Dias, C. (2001). Corporate portals: A literature review of a new concept in information management. International Journal of Information Management, 21, 269-287.

Dolfsma, W., \& Seo, D. B. (2013). Government policy and technological innovation - A suggested typology. Technovation, 33, 173-179.

Dunleavy, P., Margetts, H., Bastow, S., \& Tinkler, J. (2006). New public management is dead - Long live digital-era governance. Journal of Public Administration Research and Theory, 16(3), 467-494.

Gartner. (2010). Magic Quadrant for Business Process Management Suites. Research 2010, ID Number: G00205212.

Gierszewski, J. (2012). Administracja publiczna. Skrypt [Public administration. Script]. PWSH POMERANIA.

Gnan, L., Hinna, A., Monteduro F., \& Scarozza D. (2013). Corporate governance and management practices: Stakeholder involvement, quality and sustainability tools adoption. Journal of Management \& Governance, 17, 907-937. 
Gupta B., Dasgupta, S., \& Gupta A. (2008). Adoption of ICT in a government organization in a developing country: An empirical study. Journal of Strategic Information Systems, 17, 140-154.

Heeks, R. (2002). Information systems and developing countries: Failure, success, and local improvisations. The Information Society: An International Journal, 18(2), 101-112.

Homburg, V. (2004). E-government and NPM: A perfect marriage? Presented at the 6th International Conference on Electronic Commerce Delft. ACM Press, The Netherlands.

Hwang, J., \& Akdede, S. H. (2011). The influence of governance on public sector efficiency: A crosscountry analysis. The Social Science Journal, 48, 735-738.

Insight Report. (2013). The Global Information Technology Report 2013, Growth and jobs in a hyperconnected world. In B. Bilbao-Osorio, S. Dutta, B. Lanvin, (Ed.). World Economic Forum, Geneva. Retrieved from: http://www3.weforum.org/docs/WEF_GITR Report_2013.pdf.

Jablonski, S. (2005). Processes, workflows, web service flows: A reconstruction. Data Management in a Connected World: Lecture Notes in Computer Science, 3551, 201-213.

Jallow, A. K., Majeed, B., Vergidis, K., Tiwari, A., \& Roy, R. (2007). Operational risk analysis in business processes. BT Technology Journal, 25(1), 168-177.

Jeston, J., \& Nelis, J. (2008). Business process management: Practical guidelines to successful implementation (2nd ed.). Oxford: Elsevier.

Kasprzak., T. (2005). Organizacja zorientowana na procesy biznesu - Modelowanie referencyjne [Business processes oriented organization - Modeling reference]. In T. Kasprzak (Ed.), Modele referencyjne $w$ zarządzaniu procesami biznesu [Reference models in business process management]. Warszawa: Difin.

Kim, Ch. K. (2007). A cross-national analysis of global e-Government. Public Organization Review, 7(4), 317-329.

Kumar, V., Maheshwari, B., \& Kumar, U. (2002). ERP systems implementation: Best practices in Canadian government organizations. Government Information Quarterly, 19, 147-172.

Lee, J., Kim, H., Seo, W., Kim, K., \& Kim, C. H. (2011). Condition-based process patterns for modeling of human processes in knowledge-intensive business services. Expert Systems with Applications, 38, 4025-4038.

Lezochea, M., Yahiaa, E., Aubrya, A., Panettoa, H., \& Zdravkovic, M. (2012). Conceptualising and structuring semantics in cooperative enterprise information systems models. Computers in Industry, 63, 775-787.

Linthicum, D. S. (2003). Next generation application integration. From simple information to web services. Addison-Wesley.

Liu, J., Zhang, E., Xiong, J., \& Lv, Z. (2006). Deployment of web services for enterprise application integration (EAI) system. Advanced Web and Network Technologies, and Applications, Lecture Notes in Computer Science, 3842, 779-782.

Lozoya-Arandia, J., \& Franco-Reboreda, C. (2012). Insights on the definition of an agenda for ICT development in municipal governments: A reference model. Procedia Technology, 3, 282-291.

Markus, M. L., \& Tanis, C. (2000). The enterprise systems experience - From adoption to success. In R. W. Zmud (Ed.), Framing the domains of IT management: Projecting the future through the past (pp.173207). Cincinnati: Pinnaflex Publishing.

Measuring the Information Society. (2013). International Telecommunication Union, Switzerland. Retrieved from: http://www.burmalibrary.org/docs16/MIS2013-ICT Development_Index.pdf

Michałek-Budzicz A., Malujda R., \& Michalski R. (2011). Analiza rynku zamówień publicznych na narzędzia informatyczne [Public procurement tools analysis]. Poznań: Fundacja Wolnego i Otwartego Oprogramowania. 
Olszak, C. M., \& Ziemba, E. (2007). Approach to building and implementing business intelligence systems. Interdisciplinary Journal of Information, Knowledge, and Management, 2, 135-148. Retrieved from http://www.ijikm.org/Volume2/IJIKMv2p135-148Olszak184.pdf

Ongondo, F. O., Williams, I. D., Dietrich, J., \& Carroll, C. (2013). ICT reuse in socio-economic enterprises. Waste Management, 33, 2600-2606.

Pillania, R. K. (2011). The state of research on technological uncertainties, social uncertainties and emerging markets: A multidisciplinary literature review. Technological Forecasting \& Social Change, 78, 1158-1163.

Pina, V., Torres, L., \& Acerete, B. (2007). Are ICTs promoting government accountability? A comparative analysis of e-governance developments in 19 OECD countries. Critical Perspectives on Accounting, $18,583-602$.

Pourshahid, A., Amyot, D., Peyton, L., Ghanavati, S., Chen, P., Weiss, M., \& Forster, A. J. (2009). Business process management with the user requirements notation. Electronic Commerce Research, 9 , 269-316.

Reddick, Ch. G. (2011). Customer relationship management (CRM) technology and organizational change: Evidence for the bureaucratic and e-Government paradigms. Government Information Quarterly, 28, 346-353.

Reddick. Ch. G., \& Turner, M. (2012). Channel choice and public service delivery in Canada: Comparing e-government to traditional service delivery. Government Information Quarterly, 29, 1-11.

Rose, W. R., \& Grant, G. G. (2010). Critical issues pertaining to the planning and implementation of egovernment initiatives. Government Information Quarterly 27, 26-33.

Saleem, M., Chung, P. W. H., Fatima, S., \& Dai, W. (2013) A cross organisation compatible workflows generation and execution framework. Knowledge-Based Systems. Retrieved from: http://dx.doi.org/10.1016/j.knosys.2013.08.022

Sambamurthy, V., \& Kirsch, L. J. (2000). An integrative framework of the information systems development process. Decision Science, 31(2), 391-411.

Samtani, G., \& Sadhwani, D. (2002). Enterprise application integration (EAI) and web services. In P. Fletcher \& M. Waterhouse (Eds.), Web services business strategies and architectures (pp. 39-54). Birmingham: Expert Press, Ltd.

Self, P. (2000). Rolling back the state. economic dogma and political choice. New York: St. Martin's Press.

Seri P., \& Zanfei, A. (2013). The co-evolution of ICT, skills, and organization in public administrations: Evidence from new European country-level data. Structural Change and Economic Dynamics 27, 160-176.

Shang, S., \& Seddon, P. B. (2002). Assessing and managing the benefits of enterprise systems: The business manager's perspective. Information Systems Journal, 12(4), 271-299.

Sheth, A. P., Aalst, W. V. D., \& Arpinar, I. B. (1999). Processes driving the networked economy. IEEE Concurrency, 7, 18-31

State 2.0. A new start for e-administration. (2012). Warszawa: Ministry of Administration and Digitization. Retrieved from: https://mac.gov.pl/wp-content/uploads/2011/12/Panstwo-2-0-do-druku_EN.pdf

Torres, L., Pina, V., \& Acerete, B. (2005). E-government developments on delivering public services among EU cities. Government Information Quarterly, 22, 217-238.

Torres, L, Pina, V., \& Acerete, B. (2006). E-Governance developments in EU cities. Reshaping government's relationship with citizens. Governance, 19(2), 277-302.

Trkman, P. (2010). The critical success factors of business process management. International Journal of Information Management, 30(2), 125-134. 
Tung, L. L., \& Rieck, O. (2005). Adoption of electronic government services among business organizations in Singapore. Journal of Strategic Information Systems, 14, 417-440.

Turban, E., Sharda, R., \& Delen, D. (2010). Decision support and business intelligence systems (9th ed.) Upper Saddle River Prentice Hall Press.

Urciuoli, L., Hintsa J., \& Ahokas J. (2013). Drivers and barriers affecting usage of e-Customs - A global survey with customs administrations using multivariate analysis techniques. Government Information Quarterly. Retrieved from http://dx.doi.org/10.1016/j.giq.2013.06.001

Valdés G., Solar, M., Astudillo, H., Iribarren, M., Concha, G., \& Visconti, M. (2011). Conception, development and implementation of an e-Government maturity model in public agencies. Government Information Quarterly, 28, 176-187

van de Donk, I., \& Stellen, W. (1998). Public administration in an information age: A handbook. Amsterdam: IOS Press.

van der Voet, J. (2013). The effectiveness and specificity of change management in a public organization: Transformational leadership and a bureaucratic organizational structure. European Management Journal. Retrieved from: http://dx.doi.org/10.1016/j.emj.2013.10.001

$\mathrm{Vu}$, K. M. (2013). Information and communication technology (ICT) and Singapore's economic growth. Information Economics and Policy, 25, 284-300.

Wang, H. J. (2009). Teaching case on SOA and web services in a system analysis and design course. Proceedings of The Nineteenth Workshop of Information Technologies and Systems Phoenix, Arizona. Retrieved from http://ssrn.com/abstract=1494564

Weber, D. M., \& Kauffman, R. J. (2011). What drives global ICT adoption? Analysis and research directions. Electronic Commerce Research and Applications, 10, 683-701.

Weerakkody, V., El-Haddadeh, R., Sabol, T., Ghoneim, A., \& Dzupka, P. (2012). E-government implementation strategies in developed and transition economies: A comparative study. International Journal of Information Management 32, 66-74.

Weerakkody, V., Janssen, M., \& Dwivedi, Y. K. (2011). Transformational change and business process reengineering (BPR): Lessons from the British and Dutch public sector. Government Information Quarterly, 28, 320-328.

Winn S., \& Oo, M. T. (2011). Multi-agent model for automation of business process management system based on service oriented architecture. World Academy of Science, Engineering and Technology, 74, 670-675.

Workflow Management Coalition. (1999). Workflow management coalition terminology and glossary (Technical Report). Retrieved from: http://www.workflowpatterns.com/documentation/documents/TC-1011 term_glossary_v3.pdf

Ziemba, E. (2009). Projektowanie portali korporacyjnych dla organizacji opartych na wiedzy [Design of corporate portals for knowledge-based organizations]. Katowice: University of Economics in Katowice.

Ziemba, E. (2013). The holistic and systems approach to the sustainable information society. Journal of Computer Information Systems, 2013, 54(1), 106-116.

Ziemba, E., \& Obłąk, I. (2012). Systemy informatyczne w organizacjach zorientowanych procesowo [Information systems in business processes oriented organizations]. Problemy Zarzadzania, 10, 8-24. Retrieved from: http://pz.wz.uw.edu.pl/sites/default/files/artykuly/ziemba_oblak.pdf

Ziemba, E., \& Papaj, T. (2013). Pragmatic approach to e-government maturity in Poland - Implementation and usage of SEKAP. In E. Ferrari \& W. Caselnovo (Eds.), Proceedings of 13th European Conference on eGovernment-ECEG 2013 (pp. 560-570). Varese: University of Insubria, Retrieved from http://issuu.com/acpil/docs/eceg13-issuu_vol_2 
Ziemba, E., \& Żelazny, R. (2013). Measuring the information society in Poland - Dilemmas and a quantified image. In M. Ganzha, L. Maciaszek, \& M. Paprzycki (Eds.), Proceedings of the 2013 Federated Conference on Computer Science and Information Systems (pp. 1185-1192). Krakow.

Zorrilla, M., \& García-Saiz, D. (2013). A service oriented architecture to provide data mining services for non-expert data miners. Decision Support Systems, 55, 399-411.

\section{Appendix}

\section{Table A1}

\begin{tabular}{|c|c|}
\hline \multicolumn{2}{|r|}{$\begin{array}{l}\text { IT project in public administration in Poland - } \\
\text { already implemented and during implementation }\end{array}$} \\
\hline Institution & The Ministry of Justice \\
\hline Name of the system & New Land and Mortgage Register (NKW) \\
\hline Name of the system (Polish) & System zakładania i prowadzenia ksiąg wieczystych \\
\hline Level & central and local \\
\hline Social benefits & $\begin{array}{l}\text { Ann individual can obtain a copy from any Land and Mortgage Register of real } \\
\text { property (flat, house or plot) without the need to leave home. He/ she can also trans- } \\
\text { fer the number obtained, e.g. to companies that may need a confirmation of the title } \\
\text { to real property, in order to conclude a service agreement. }\end{array}$ \\
\hline Objectives & $\begin{array}{l}\text { The project objective is to improve conditions for running business operations in the } \\
\text { real estate market and the convenience of individuals by ensuring better access of } \\
\text { natural and legal persons to the IT Land and Mortgage Register. }\end{array}$ \\
\hline Institution & Centre of IT Projects reporting to MAC \\
\hline Name of the system & $\begin{array}{l}\text { Location and Information Platform with Central Database (Polish acronym PLI } \\
\text { CBD) }\end{array}$ \\
\hline Name of the system (Polish) & Platforma Lokalizacyjno Informacyjna z Centralną Bazą Danych \\
\hline Level & central \\
\hline Social benefits & $\begin{array}{l}\text { The Quick identification of where an emergency call was made from (it is essential } \\
\text { when an incident witness or casualty does not know his/ her location, or is not able } \\
\text { to state it for safety or health reasons or the property of citizens is endangered, e.g. } \\
\text { in case of fire). }\end{array}$ \\
\hline Objectives & $\begin{array}{l}\text { The Location and Information Platform with Central Database is a part of the na- } \\
\text { tionwide IT Emergency Communication System. The platform itself is used to } \\
\text { maintain the database with data on the users of public telephone networks and to } \\
\text { provide the systems and services, which are responsible for receiving emergency } \\
\text { calls, with information on end locations of (fixed and mobile) telephone networks, } \\
\text { from which emergency calls were made. }\end{array}$ \\
\hline Institution & Centre of IT Projects reporting to Ministry of Administration and Digitization \\
\hline Name of the system & $\begin{array}{l}\text { Country-wide data communication network to support emergency phone number } \\
\text { "112" }\end{array}$ \\
\hline Name of the system (Polish) & Ogólnopolska sieć teleinformatyczna obsługi numeru alarmowego „112” \\
\hline Level & central and local \\
\hline Social benefits & Average time of reaching persons calling for medical assistance will be reduced. \\
\hline Objectives & $\begin{array}{l}\text { The objective of the project is to implement an integrated nationwide data commu- } \\
\text { nication network to support emergency phone number 112, including terminals for } \\
\text { the appropriate rescue services and public order services (Police, Fire Brigade, } \\
\text { Provincial Emergency Communication Centres, Provincial Offices), as well as to } \\
\text { provide mechanisms for the management, maintenance and monitoring of the net- } \\
\text { work status and service quality. }\end{array}$ \\
\hline
\end{tabular}




\begin{tabular}{|c|c|}
\hline \multicolumn{2}{|r|}{$\begin{array}{l}\text { IT project in public administration in Poland - } \\
\text { already implemented and during implementation }\end{array}$} \\
\hline Institution & Ministry of the Interior (implemented by the Centre of IT Projects) \\
\hline Name of the system & $\begin{array}{l}\text { Integrated, multi-service communication platform for the Police with e-Services for } \\
\text { individuals and businessmen }\end{array}$ \\
\hline Name of the system (Polish) & $\begin{array}{l}\text { Zintegrowana, wielousługowa platforma komunikacyjna Policji z funkcją eUsług } \\
\text { dla obywateli i przedsiębiorców }\end{array}$ \\
\hline Level & central and local \\
\hline Social benefits & $\begin{array}{l}\text { Such services as: e-gun licences, e-licences (detective licence, licences for security } \\
\text { staff and technical support staff), e-complaint and e-appeal, will be available in the } \\
\text { form of electronic forms available on ePUAP. Thanks to the integration with the } \\
\text { users folder built on the basis of an internal portal, it will be possible to quickly find } \\
\text { the person, or group of persons searched for, as well as to select the appropriate } \\
\text { communication channel, e.g. text messages, IP telephony or video conferences. } \\
\text { Talks and meetings held with the use of the system can be registered and published } \\
\text { on internal and/or external information portals for educational or information pur- } \\
\text { poses. }\end{array}$ \\
\hline Objectives & $\begin{array}{l}\text { To build a system supporting police services through electronic channels. The sys- } \\
\text { tem must also make police work more efficient. The e-auctions module must allow } \\
\text { sales through Internet auctions, while e-orders must support handling of public } \\
\text { orders. }\end{array}$ \\
\hline Institution & The Main Statistical Office \\
\hline Name of the system & Public Statistics Information System (SISP) \\
\hline Name of the system (Polish) & System Informacyjny Statystyki Publicznej (SISP) \\
\hline Level & central \\
\hline Social benefits & $\begin{array}{l}\text { Businessmen and other liable entities may submit statistical documents in an elec- } \\
\text { tronic format. }\end{array}$ \\
\hline Objectives & $\begin{array}{l}\text { To strengthen the role of public statistics in the state's information infrastructure by } \\
\text { implementing e-Statistics, that is, by providing a system for public communication } \\
\text { of statistics }\end{array}$ \\
\hline Institution & Social Insurance Institution (ZUS) \\
\hline Name of the system & Electronic Services Platform (PUE) for customers \\
\hline Name of the system (Polish) & Platforma Usług Elektronicznych dla klientów ZUS (PUE) \\
\hline Level & central \\
\hline Social benefits & $\begin{array}{l}\text { Improved standards of customer service, better ZUS customer service, and a lower } \\
\text { number of visits to ZUS branches owing to ZUS information services being acces- } \\
\text { sible over the telephone, Internet, and automatic office stations. }\end{array}$ \\
\hline Objectives & $\begin{array}{l}\text { The main objective of the project at its strategic level is to increase access to ZUS } \\
\text { services offered in electronic form and distributed over various access channels } \\
\text { down to individuals and businessmen. }\end{array}$ \\
\hline Institution & Social Insurance Company ZUS \\
\hline Name of the system & Development of the ZUS IT system supporting access to e-Services \\
\hline Name of the system (Polish) & Rozwój systemu informatycznego ZUS wspomagającego udostępnianie e-Usług \\
\hline Level & central \\
\hline Social benefits & $\begin{array}{l}\text { Better accessibility and security of electronic services provided to payers and to the } \\
\text { systems serving ZUS inspectors. }\end{array}$ \\
\hline Objectives & $\begin{array}{l}\text { Improved continuity, efficiency, and security of services provided to the public by } \\
\text { the ZUS (e-Services included). This will ensure a better accessibility and security of } \\
\text { electronic services provided to payers, a better performance of the technical and } \\
\text { systemic infrastructure which is used by systems serving ZUS inspectors via the } \\
\text { Internet. }\end{array}$ \\
\hline
\end{tabular}




\begin{tabular}{|c|c|}
\hline \multicolumn{2}{|r|}{$\begin{array}{l}\text { IT project in public administration in Poland - } \\
\text { already implemented and during implementation }\end{array}$} \\
\hline Institution & The Ministry of Labour and Welfare Policy \\
\hline Name of the system & Emp@tia--a communication platform for the social security area \\
\hline Name of the system (Polish) & Emp@tia - platforma komunikacyjna obszaru zabezpieczenia społecznego \\
\hline Level & central and local \\
\hline Social benefits & $\begin{array}{l}\text { Electronic access to information will reduce the need and frequency of visits to } \\
\text { welfare center }\end{array}$ \\
\hline Objectives & $\begin{array}{l}\text { Building a broad communication platform for the social security area that will en- } \\
\text { able delivering and providing electronic services to both, welfare beneficiaries, } \\
\text { family allowance users, the alimony fund, small and medium-sized enterprises } \\
\text { which serve as technological suppliers to the data communications systems support- } \\
\text { ing the welfare security area. }\end{array}$ \\
\hline Institution & The Head Office of Geodesy and Cartography \\
\hline Name of the system & $\begin{array}{l}\text { Georeference Database of Topographic Objects and the national management sys- } \\
\text { tem }\end{array}$ \\
\hline Name of the system (Polish) & $\begin{array}{l}\text { Georeferencyjna Baza Danych Obiektów Topograficznych wraz z krajowym } \\
\text { systemem zarządzania }\end{array}$ \\
\hline Level & central \\
\hline Social benefits & $\begin{array}{l}\text { Fire brigades, police forces, and ambulance services even when operating in an } \\
\text { unfamiliar area, are able to quickly identify features important to them, such as: } \\
\text { access roads, hydrants, trees blocking the way, canals, etc. Designers, architects and } \\
\text { urban planners get precise, updated information about the area and surveyors are } \\
\text { able to do precision measurements based on a sophisticated grid of reference points. } \\
\text { Developers are able to quickly and easily identify infrastructures, such as: roads, rail } \\
\text { roads, installations, natural objects, water flows, natural terrain features, and the } \\
\text { ecological features of the areas where they plan their development projects (rational } \\
\text { land management planning). Data base records are accessible via the API. }\end{array}$ \\
\hline Objectives & $\begin{array}{l}\text { An analysis, collection, processing, and releasing of spatial information to busi- } \\
\text { nessmen, public, and administration of all levels on Geoportal and other platforms, } \\
\text { which cover the country's territory and comes in a resolution corresponding with } \\
\text { topographic maps at scales } 1: 10,000 \text { and } 1: 50,000 \text {. }\end{array}$ \\
\hline Institution & The Main Office of Geodesy and Cartography \\
\hline Name of the system & $\begin{array}{l}\text { TERYT2--The national registry of plot boundaries and areas of state territory divi- } \\
\text { sion units. }\end{array}$ \\
\hline Name of the system (Polish) & $\begin{array}{l}\text { TERYT2 - Państwowy rejestr granic i powierzchni jednostek podziałów } \\
\text { terytorialnych kraju }\end{array}$ \\
\hline Level & central \\
\hline Social benefits & $\begin{array}{l}\text { The people will be able to identify their appropriate tax office, court of law, prose- } \\
\text { cutor's office, and other government agencies, while developers will be able to } \\
\text { quickly check which Water Management Authority or State Forestry Management } \\
\text { is appropriate for the area of their interest, and rescue services will be able to } \\
\text { quickly reach the accident locations by using the updated, official address data. All } \\
\text { the electronic services provided by the administration will rely on the same listings } \\
\text { of streets and building addresses, without the need to enter and check them each } \\
\text { time they are called by someone. }\end{array}$ \\
\hline Objectives & $\begin{array}{l}\text { The project will open on-line access to the state registry of plot boundaries and } \\
\text { areas of the state territory division units, and it will implement solutions related to } \\
\text { the operation of address registers. During the project implementation, a new-quality } \\
\text { register will be set up by expanding and supplementing the existing descriptive data } \\
\text { bases (e.g., TERYT) through adding to them the relevant geometric data and de- } \\
\text { scriptive data integrated with the existing graphic data. }\end{array}$ \\
\hline
\end{tabular}




\begin{tabular}{|c|c|}
\hline \multicolumn{2}{|r|}{$\begin{array}{l}\text { IT project in public administration in Poland - } \\
\text { already implemented and during implementation }\end{array}$} \\
\hline Institution & Ministry of Finance \\
\hline Name of the system & Infrastructure of the Finance Ministry e-Services \\
\hline Name of the system (Polish) & Infrastruktura e-Usług Resortu Finansów \\
\hline Level & central and local \\
\hline Social benefits & $\begin{array}{l}\text { Modernized treasury administration enables it to work more productively and re- } \\
\text { spond more quickly to inquiries from people. }\end{array}$ \\
\hline Objectives & $\begin{array}{l}\text { Project implementation will ensure efficient rendering of e-Services to the public } \\
\text { and business sectors, and will enhance the use of e-Services by providing appropri- } \\
\text { ate information support for the infrastructure of e-Services rendered by the Finance } \\
\text { Ministry. It will, moreover, provide a flexible data transmission environment to the } \\
\text { remote network of the Finance Ministry, to stimulate the development of advanced } \\
\text { public services offered over electronic channels (including information exchange } \\
\text { between the systems of the Finance Ministry and their Central EU Systems. }\end{array}$ \\
\hline Institution & Communication Institute \\
\hline Name of the system & $\begin{array}{l}\text { The system of information about Broadband Infrastructure and the "Broadband } \\
\text { Poland" portal }\end{array}$ \\
\hline Name of the system (Polish) & $\begin{array}{l}\text { System Informacyjny o Infrastrukturze Szerokopasmowej i portal „Polska } \\
\text { Szerokopasmowa” }\end{array}$ \\
\hline Level & local \\
\hline Social benefits & $\begin{array}{l}\text { By getting information about Poland's broadband network, a businessman may } \\
\text { quickly find out about the infrastructure in the area where he is going to provide his } \\
\text { Internet access service. A Starost or Head of Village can easily check where in his } \\
\text { area the infrastructure has been properly developed and where it needs to be further } \\
\text { upgraded or modernized. }\end{array}$ \\
\hline Objectives & $\begin{array}{l}\text { This project comprises of building a System of Information about Broadband Infra- } \\
\text { structure--a data communications system for gathering, processing, presenting, and } \\
\text { releasing information about the telecommunication infrastructure, public telecom- } \\
\text { munication networks, and buildings used for collocation. The objective of the Sys- } \\
\text { tem of Information about the Broadband Infrastructure project is to build up knowl- } \\
\text { edge about the data communications infrastructure with nationwide reach, that will } \\
\text { give support to central and local government administration in its management and } \\
\text { co-ordination of projects related to building a regional, broadband framework and } \\
\text { access networks in areas requiring intervention. This infrastructure will support the } \\
\text { work of central and local government by providing support for the electronic public } \\
\text { services provided to the individuals and entrepreneurs. An additional aim of the } \\
\text { project is to promote information society services among the residents of areas } \\
\text { threatened with digital exclusion. }\end{array}$ \\
\hline Institution & Ministry of Justice \\
\hline Name of the system & Central Registry and Information about Business Activities (CEIDG) \\
\hline Name of the system (Polish) & Centralna Ewidencja i Informacja o Działalności Gospodarczej (CEIDG) \\
\hline Level & central \\
\hline Social benefits & $\begin{array}{l}\text { All individuals with a trusted profile or electronic signature can within } 15 \text { minutes } \\
\text { clear all the formalities required to immediately start up a new business. }\end{array}$ \\
\hline Objectives & $\begin{array}{l}\text { The main objective of the Project is to implement a system for building up and } \\
\text { running a central registry of businesses, providing information about the entries in } \\
\text { the central business records, in-creasing the security of business transactions by } \\
\text { providing information about entrepreneurs entered in the registry of enterprises. }\end{array}$ \\
\hline
\end{tabular}




\begin{tabular}{|c|c|}
\hline \multicolumn{2}{|r|}{$\begin{array}{l}\text { IT project in public administration in Poland - } \\
\text { already implemented and during implementation }\end{array}$} \\
\hline Institution & Institute of Meteorology and Water Management \\
\hline Name of the system & IT System for Protecting the Country against Emergencies \\
\hline Name of the system (Polish) & Informatyczny System Osłony Kraju przed nadzwyczajnymi zagrożeniami (ISOK) \\
\hline Level & central \\
\hline Social benefits & $\begin{array}{l}\text { It will be possible to forecast effects of natural disasters a longer period of time in } \\
\text { advance than now. Thanks to the estimation of the property value in a given area, it } \\
\text { is possible to estimate an incidence of losses caused by, e.g. hurricane, fire or other } \\
\text { natural disaster. Thanks to the system, effects of, e.g. a floodbank failure can be } \\
\text { simulated. }\end{array}$ \\
\hline Objectives & $\begin{array}{l}\text { The fundamental objective of the project is to create an uniform IT system, ready } \\
\text { for common use, in order to protect the society against emergencies and to support a } \\
\text { decision-making process if life and health threatening events occur in a given area. }\end{array}$ \\
\hline Institution & Main Office for Geodesy and Cartography \\
\hline Name of the system & Geoportal 2 \\
\hline Name of the system (Polish) & Geoportal 2 \\
\hline Level & central \\
\hline Social benefits & $\begin{array}{l}\text { Before purchasing a plot of land, it will be possible to electronically obtain data on } \\
\text { the plot (roads and utilities, water courses, protected species, flood hazard, etc.) and } \\
\text { discuss the purchase of e.g. aerial photographs, topographic maps, information on } \\
\text { routes of borders (including online payment module). Electronic communication } \\
\text { between the geodetic contractor and the center of geodetic and cartographic docu- } \\
\text { mentation will be provided, which will reduce the need for the contractor to pay } \\
\text { visits in person to the office }\end{array}$ \\
\hline Objectives & $\begin{array}{l}\text { The main objective of the project is to enable citizens universal access to and use } \\
\text { spatial information in Poland through the expansion of the national spatial informa- } \\
\text { tion infrastructure in the scope of georeferencing registers and related services. Data } \\
\text { collected as a part of GBDOT project is, among others, published. The project } \\
\text { assumes the integration and harmonization of services and spatial information } \\
\text { through the use of georeferencing/ base registers, as well as the co-ordination of } \\
\text { activities in accordance with the State's information infrastructure model and as- } \\
\text { sumptions of the INSPIRE Directive. }\end{array}$ \\
\hline Institution & Ministry of the Interior \\
\hline Name of the system & pl.ID - Polish ID card \\
\hline Name of the system (Polish) & pl.ID - Polska ID karta \\
\hline Level & central \\
\hline Social benefits & $\begin{array}{l}\text { Ultimately, the number of cases when, in order to fix official matters (e.g. vehicle } \\
\text { registration or making a marriage), a citizen is required to present documents when } \\
\text { giving individual data (stored in public registers), will decrease Rebuild, upgrade } \\
\text { and integrate the existing state registers, }\end{array}$ \\
\hline Objectives & $\begin{array}{l}\text { Ensure compatibility with the European electronic identity document (eID) - } \\
\text { Computerize the registers of Registry Offices, -Implement electronic ID card with } \\
\text { an option of authentication in the IT systems of public sector entities. }\end{array}$ \\
\hline
\end{tabular}




\begin{tabular}{|c|c|}
\hline \multicolumn{2}{|r|}{$\begin{array}{l}\text { IT project in public administration in Poland - } \\
\text { already implemented and during implementation }\end{array}$} \\
\hline Institution & IT Projects Centre \\
\hline Name of the system & Building and equipping the Emergency Information Centres \\
\hline Name of the system (Polish) & System Informatyczny Powiadamiania Ratunkowego (SIPR) \\
\hline Level & central and local \\
\hline Social benefits & $\begin{array}{l}\text { Cutting short the emergency alarm response time and improving the success rate of } \\
\text { alerting rescue services and structures. Standardization of procedures. }\end{array}$ \\
\hline Objectives & $\begin{array}{l}\text { Improve the security of citizens and foreigners present in the territory of Poland: } \\
\text { integration of the services on duty at the respective entities appointed by the law to } \\
\text { provide rescue in particular, the Fire Brigades, the Police Force, and the State Medi- } \\
\text { cal Aid, to significantly improve the collaborative efficiency of those structures. Cut } \\
\text { short the response time and improve the success rate of alarms sent to rescue ser- } \\
\text { vices and structures. Improve the working conditions of public order enforcement } \\
\text { and rescue officers/staff through providing services which guarantee quick access to } \\
\text { information. Rational spending public money through minimization of the cost of } \\
\text { organization and current operation of the Emergency Information System. }\end{array}$ \\
\hline Institution & The Ministry of Health/Centre of Health Protection Information Systems \\
\hline Name of the system & $\begin{array}{l}\text { Electronic Platform to Gather, Analyse, and Release Digital Resource on Medical } \\
\text { Events (P1) }\end{array}$ \\
\hline Name of the system (Polish) & $\begin{array}{l}\text { Elektroniczna Platforma Gromadzenia, Analizy i Udostępniania Zasobów } \\
\text { Cyfrowych o Zdarzeniach Medycznych (P1) }\end{array}$ \\
\hline Level & central and local \\
\hline Social benefits & $\begin{array}{l}\text { Services rendered to the public and to entities offering and delivering medical ser- } \\
\text { vices (i.e. access to medial data and information, including case histories, treatments } \\
\text { received, key medical data, such as, blood type, possibilities to book surgery ap- } \\
\text { pointments, making electronic prescriptions, referrals, and sick leave certificates } \\
\text { only to eligible persons in line with the law on access to personal data). } \\
\text { The main objective of the project is to allow public organs, including the central and } \\
\text { local government agencies, businessmen, and the public to gather, analyze, and } \\
\text { release digital resource on medical events, improve the processes of planning and } \\
\text { providing health services, and publishing information on health protection subjects. }\end{array}$ \\
\hline Institution & The Ministry of Health/Centre of Health Protection Information Systems \\
\hline Name of the system & $\begin{array}{l}\text { Platform available on-line to entrepreneurs who need access to services and digital } \\
\text { medical registry resource }(\mathrm{P} 2)\end{array}$ \\
\hline Name of the system (Polish) & $\begin{array}{l}\text { Platforma udostępniania online przedsiębiorcom usług i zasobów cyfrowych } \\
\text { rejestrów medycznych (P2) }\end{array}$ \\
\hline Level & central \\
\hline Social benefits & $\begin{array}{l}\text { Allowing business and public institutions to get registered electronically, to update } \\
\text { their registry data, and to retrieve extracts and certificates from them. }\end{array}$ \\
\hline Objectives & $\begin{array}{l}\text { The aim of this project is to build an electronic platform of public services in the } \\
\text { health protection sector: "Platform available on-line to entrepreneurs who need } \\
\text { access to services and digital medical registry resource." The detailed objective of } \\
\text { the project is to promote electronic communication among companies and public } \\
\text { entities of the health sector. }\end{array}$ \\
\hline
\end{tabular}




\begin{tabular}{|c|c|}
\hline \multicolumn{2}{|r|}{$\begin{array}{l}\text { IT project in public administration in Poland - } \\
\text { already implemented and during implementation }\end{array}$} \\
\hline Institution & Ministry of Justice \\
\hline Name of the system & Building an electronic services system for the Ministry of Justice \\
\hline Name of the system (Polish) & Budowa systemu usług elektronicznych Ministerstwa Sprawiedliwości \\
\hline Level & central \\
\hline Social benefits & $\begin{array}{l}\text { The people will no longer have to submit the clean criminal record certificates } \\
\text { because the government staff will have access to the National Crime Index. The } \\
\text { people will get an on-line access to information in the Court and Economic Monitor } \\
\text { which is vital especially in bankruptcy, auction, and other such procedures. Full } \\
\text { electronic handling of cases, which could be done on-line only to some extent be- } \\
\text { fore, down to issuing the decision and making a payment. }\end{array}$ \\
\hline Objectives & $\begin{array}{l}\text { The main objective of the project is to improve the conditions of doing business by } \\
\text { giving individuals and companies an electronic information platform of the Ministry } \\
\text { of Justice on which services requiring communication with the administration of } \\
\text { justice will be available. }\end{array}$ \\
\hline Institution & Ministry of Finance \\
\hline Name of the system & e-Deklaracje2 \\
\hline Name of the system (Polish) & eDeklaracje2 \\
\hline Level & central \\
\hline Social benefits & $\begin{array}{l}\text { Simplification of disclosure duties by releasing some tax payers from making out } \\
\text { tax documents (PFR system) and simplification and consolidation of tax statement } \\
\text { forms submitted by the other tax payers and payers. }\end{array}$ \\
\hline Objectives & $\begin{array}{l}\text { The main objective of the project is to improve the process of information exchange } \\
\text { between the tax authorities and its clients. }\end{array}$ \\
\hline Institution & Ministry of Finance \\
\hline Name of the system & e-Taxes \\
\hline Name of the system (Polish) & ePodatki \\
\hline Level & central \\
\hline Social benefits & $\begin{array}{l}\text { Improvement of the operation of tax services (building an integrated solution to } \\
\text { simplify the collection and checking of tax statements). }\end{array}$ \\
\hline Objectives & $\begin{array}{l}\text { The strategic objective of the project is to simplify the system of tax collection by } \\
\text { improving the internal business processes in the tax administration. }\end{array}$ \\
\hline Institution & Ministry of Finance \\
\hline Name of the system & e-Registration \\
\hline Name of the system (Polish) & eRejestracja \\
\hline Level & central \\
\hline Social benefits & $\begin{array}{l}\text { Decrease in the number of applications for NIP numbers (since September 1, } 2011 \\
\text { these are generated by using the system after application by the citizen). Decrease in } \\
\text { the amount of identification data given in PIT tax declarations. Shortening of the } \\
\text { average time for issuing NIP for persons starting business activity. Making possible } \\
\text { the exchange of identification data with other public registers for the identification } \\
\text { of citizens or Companies. Exemption from the registration duty of tax payers and } \\
\text { payers recorded in PESEL and KRS registers. }\end{array}$ \\
\hline Objectives & $\begin{array}{l}\text { The main goal of the Project is facilitation of the registration and recording proce- } \\
\text { dures of tax payers and payers. }\end{array}$ \\
\hline
\end{tabular}




\begin{tabular}{|c|c|}
\hline \multicolumn{2}{|r|}{$\begin{array}{l}\text { IT project in public administration in Poland - } \\
\text { already implemented and during implementation }\end{array}$} \\
\hline Institution & Ministry of Finance \\
\hline Name of the system & Program e-Duty \\
\hline Name of the system (Polish) & Program eCło \\
\hline Level & central \\
\hline Social benefits & $\begin{array}{l}\text { Shortening in time and simplification of customs and tax declarations in interna- } \\
\text { tional trade tax (inside and outside of the EU). Simplification of customs and tax } \\
\text { control in international trade. }\end{array}$ \\
\hline Objectives & $\begin{array}{l}\text { The main goal of the e-Duty Project is the creation of an ICT systems environment } \\
\text { enabling the implementation of digital systems for customs clearances, and at the } \\
\text { same time securing the best possible conditions for functioning of Companies in the } \\
\text { Customs Union. Thanks to the building and integration of the components of the e- } \\
\text { Duty Program conditions will be created for a successful, secure and effective ex- } \\
\text { change of data with businessmen, custom administrations of other Member States } \\
\text { and the European Commission and collaborating institutions, what will be the im- } \\
\text { plementation of a Community initiative "e-Customs" on national ground. }\end{array}$ \\
\hline Institution & Ministry of Finance \\
\hline Name of the system & ePUAP2 - Electronic Platform of Public Administration Services \\
\hline Name of the system (Polish) & Elektroniczna Platforma Usług Administracji Publicznej ePUAP2 \\
\hline Level & central \\
\hline Social benefits & $\begin{array}{l}\text { After giving of user name and password (trusted profile or digital signature) it will } \\
\text { be possible for any citizen to conduct business digitally in local government institu- } \\
\text { tions, ZUS, tax administration, health care and use the services delivered electroni- } \\
\text { cally by these institutions via PUAP. Services created/made available by the rele- } \\
\text { vant departments within the framework of different projects will encompass, among } \\
\text { other things, submission of tax declarations, obtaining of certificates and social } \\
\text { benefits, car registration, obtaining of permission for construction work. For busi- } \\
\text { nessmen, within the framework of other projects connected with the mechanisms of } \\
\text { the ePUAP platform, the electronic execution of administrative duties towards the } \\
\text { State (ZUS, taxes, Vat declarations and notifications, custom declarations, statistic } \\
\text { declarations, permissions and certificates) is planned. The same procedures in dif- } \\
\text { ferent offices and local governments will be processed in a similar way. }\end{array}$ \\
\hline Objectives & $\begin{array}{l}\text { The main goal of the ePUAP2 project is the creation of one, easy accessible and } \\
\text { secure channel for making available public services to citizens and granting access } \\
\text { to a Trusted Profile for the authorization of the citizen in contact with the admini- } \\
\text { stration. }\end{array}$ \\
\hline
\end{tabular}

Source: based on (State 2.0, 2012). 
Table A2

\begin{tabular}{|c|c|}
\hline \multicolumn{2}{|c|}{ Table 2: IT project in public administration in Poland - planned } \\
\hline Institution & Office of Electronic Communications \\
\hline Name of the system & Platform for e-Services of Office of Electronic Communications \\
\hline Name of the system (Polish) & Budowa platformy e-usług Urzędu Komunikacji Elektronicznej \\
\hline Level & central level \\
\hline Social benefits & $\begin{array}{l}\text { Applications, complaints, etc. can be filed online with the Office. The system will } \\
\text { streamline the issue of decisions and permits, as well as enabling the user to elec- } \\
\text { tronically inspect the progress in cases. }\end{array}$ \\
\hline Objectives & $\begin{array}{l}\text { The project objective is to develop an IT system for the Office of Electronic Com- } \\
\text { munications. }\end{array}$ \\
\hline Institution & Supreme Audit Office \\
\hline Name of the system & $\begin{array}{l}\text { Integrated electronic platform for collecting, analysing and making state audit } \\
\text { results available }\end{array}$ \\
\hline Name of the system (Polish) & $\begin{array}{l}\text { Zintegrowana elektroniczna platforma gromadzenia, analizy i udostępniania } \\
\text { wyników kontroli państwowej }\end{array}$ \\
\hline Level & central level \\
\hline Social benefits & $\begin{array}{l}\text { Providing remote access to documents and knowledge accumulated by the Su- } \\
\text { preme Audit Office (Polish acronym NIK). Possibility of creating summaries and } \\
\text { making analyses on the basis of de-tailed audit results. Enabling electronic com- } \\
\text { munication between the Supreme Audit Office and recipients (including submis- } \\
\text { sion of explanations, sending documents). }\end{array}$ \\
\hline Objectives & $\begin{array}{l}\text { The objective of the project is to strengthen and modernize the state control exer- } \\
\text { cised by the Supreme Audit Office through streamlining the auditing process im- } \\
\text { plemented by the Supreme Audit Office in the areas of planning, implementation, } \\
\text { monitoring and making available audit results }\end{array}$ \\
\hline Institution & Ministry of Justice \\
\hline Name of the system & Business Information Centre (Polish acronym CIG) of the Ministry of Justice \\
\hline Name of the system (Polish) & Centrum Informacji Gospodarczej Ministerstwa Sprawiedliwości (CIG) \\
\hline Level & central level \\
\hline Social benefits & $\begin{array}{l}\text { Time of preparatory proceedings will be reduced (easier information integration } \\
\text { between various registers kept by the Ministry of Justice) }\end{array}$ \\
\hline Objectives & $\begin{array}{l}\text { The main objective of this project is to extend the scope of access by natural and } \\
\text { legal persons to information and data collected and processed by the units of the } \\
\text { Ministry of Justice (this applies to information resources contained in the court } \\
\text { registers of New Land and Mortgage Register, National Court Register, Register of } \\
\text { Pledges, Court and Business Gazette }\end{array}$ \\
\hline
\end{tabular}

Source: based on (State 2.0, 2012). 


\section{Biographies}

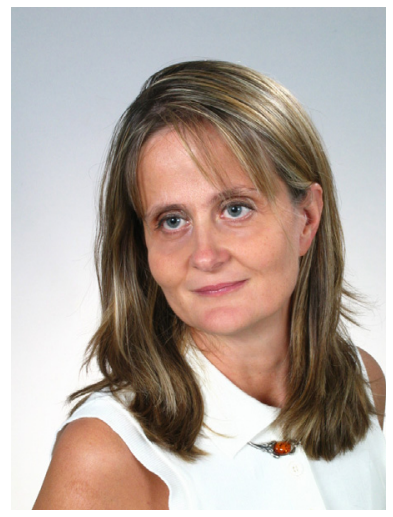

Ewa Ziemba is an associate Professor of Management Information Systems at the University of Economics in Katowice, Poland. Her research interests include information systems for knowledge management, e-business systems and information society. She has more than 150 refereed publications as books, journal papers and papers in conference proceedings. She has participated in several Polish and European research projects. Her current research project deals with designing a system approach to sustainable development of the information society. Her academic qualifications have been combined with practical experience - she has been working as the IT Project Manager for over ten years. Furthermore, she is a member of Polish Academy of Sciences (Poland), Polish Society for Business Informatics (Poland), Informing Science Institute (USA), International Association for Computer Information Systems (USA) and International Institute for Applied Knowledge Management (USA).

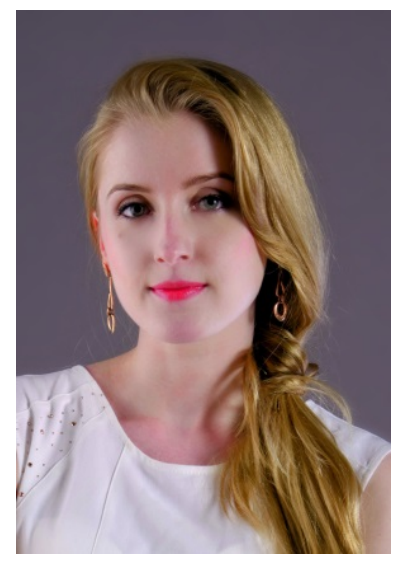

Iwona Obłąk is a PRINCE@2 Practitioner certified Information Technology Project Manager. She is experienced in IS development and implementation. She provides project management services to government clients. She has also a background in business analysis. Her principal research areas are focused on business process management, information systems in public administration (ERP, BI, BPM), Business Process Modeling, Business Analysis and Business Intelligence. 